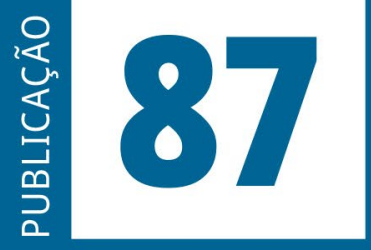

ISSN: 0101-9562

ISSN ELETRÔNICO: 2177-7055

SEQÜENCIA

Publicação do

Programa de Pós-Graduação em Direito da UFSC

VOLUME 42 - ANO 2021
Estudos jurídicos e políticos 
SEQUÊNCIA - ESTUDOS JURÍDICOS E POLÍTICOS é uma publicação temática e de periodicidade quadrimestral, editada pelo Programa de Pós-Graduação Stricto Sensu em Direito da Universidade Federal de Santa Catarina - UFSC.

SEQUÊNCIA - ESTUDOS JURÍDICOS E POLÍTICOS is a thematic publication, printed every four months, edited by the Program in law of the Federal University of Santa Catarina - UFSC.

Versão eletrônica: http://www.periodicos.ufsc.br/index.php/sequencia

A publicação é indexada nas seguintes bases de dados e diretórios/

The Publication is indexed in the following databases and directories:

Base OJS

Base PKP

CCN (Catálogo Coletivo Nacional)

Dialnet

DOAJ (Directory of Open Access Journals)

EBSCOhost

Genamics Journalseek

ICAP (Indexação Compartilhada de Artigos de Periódicos)

Latindex

LivRe!

OJS
PKP
Portal de Periódicos UFSC
Portal do SEER
ProQuest
SciELO
Sherpa/Romeo
Sumarios.org
ULRICH'S
vLex

Ficha catalográfica

Seqüência: Estudos jurídicos e políticos. Universidade Federal de Santa Catarina.

Programa de Pós-Graduação em Direito. n.1 (janeiro 1980)-.

Florianópolis: Fundação José Boiteux. 1980-.

Publicação contínua

Resumo em português e inglês

Versão impressa ISSN 0101-9562

Versão on-line ISSN 2177-7055

1. Ciência jurídica. 2. Teoria política. 3. Filosoia do direito. 4. Periódicos.

I. Universidade Federal de Santa Catarina. Programa de Pós-graduação em

Direito

CDU 34(05)

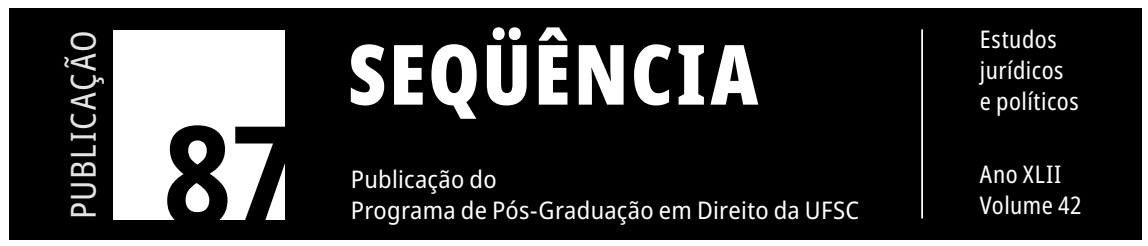




\title{
Justiça Restaurativa em Risco: a crítica criminológica ao modelo judicial brasileiro
}

\author{
Restaurative Justice at Risk: the criminological \\ critique to the Brazilian judicial model
}

Salo Carvalho

Universidade Federal do Rio de Janeiro,

Rio de Janeiro, Brasil

Daniel Achutti

IBGEN Business School, Porto Alegre, Brasil

RESUMO: A partir do acúmulo prático-teórico da criminologia crítica e do abolicionismo penal (teorias de base), o trabalho analisa, através do estudo de casos (procedimento metodológico), a eficácia dos substitutivos penais e processuais penais no Brasil. A experiência nacional em relação à forma de implementação dos Juizados Criminais (Lei 9.099/95), das penas alternativas (Lei 9.714/98) e das cautelares diversas da prisão provisória (Lei 12.403/11), agregada aos primeiros diagnósticos sobre a execução das práticas restaurativas, permite projetar os riscos de inefetividade ou o desvirtuamento dos seus objetivos principais. A hipótese desenvolvida no artigo é a de que a formação (e a ação) autoritária do Poder Judiciário brasileiro tem impedido o pleno desenvolvimento dos institutos descarcerizadores, em geral, e da Justiça Restaurativa, em particular. Neste sentido, indica a necessidade de as práticas restaurativas serem orientadas pelas diretrizes apontadas pela criminologia crítica e pelo abolicionismo, precisamente no que diz respeito ao desenvolvimento de uma lógica anticarcerária que se oponha ao punitivismo e ao inquisitorialismo.

PALAVRAS-CHAVE:Justiça Restaurativa - Criminologia Crítica - Abolicionismo - Prisões

ABSTRACT: Based on the practical-theoretical accumulation of critical criminology and penal abolitionism (basic theories), the work analyzes, through case studies (methodological procedure), the effectiveness of substitutes for penal and penal procedures in Brazil. The experience accumulated in relation to the form of 
implementation of Small Claim Courts (Law 9.099/95), of alternative penalties (Law 9.714/98) and of precautionary measures other than provisional imprisonment (Law 12.403/11), added to the first diagnoses on the execution of the restorative practices, allows to project the risks of ineffectiveness or the distortion of its main objectives. The hypothesis developed in the article is that the authoritarian formation (and action) of the Brazilian Judiciary Power has prevented the full development of the decarcerizing institutes, in general, and of Restorative Justice, in particular. In this sense, it indicates the need for restorative practices to be guided by the guidelines pointed out by critical criminology and penal abolitionism, precisely with regard to the development of an anti-prison logic that opposes to punitivism and inquisitorialism.

KeY WORDS: Restorative Justice - Critical Criminology - Abolitionism - Prisons

\section{INTRODUÇÃo}

1.1. Após mais de um século de existência é possível afirmar que a criminologia nasceu e se desenvolveu em crise. A criminologia é crise ou, no mínimo, está em permanente crise. O estado de crise é possivelmente a única variável constante no pensamento criminológico. Variável que se faz presente desde o debate epistemológico sobre a validade do seu estatuto científico, a partir da problematização do seu objeto e seus métodos de investigação, às tarefas (funções) que são atribuídas aos criminólogos.

Mas a assertiva sobre a crise constitutiva da criminologia precisa ser submetida ao questionamento dos seus motivos: qual a razão desta fundação instável ou até mesmo temerária?

Um dos indicativos possíveis desta crise seminal é o fato de a emergência da criminologia, como disciplina científica e autônoma, ter ocorrido nas entranhas de uma instituição cujo fracasso é igualmente a sua marca de constituição e desenvolvimento: a instituição carcerária. Na hipótese foucaultiana, “(...) logo a seguir a prisão, em sua realidade e seus efeitos visíveis, foi denunciada como o grande fracasso da justiça penal; (...) a crítica da prisão e de seus métodos aparece muito cedo, nesses mesmos anos de 1820-1845; ela aliás se fixa num certo número de formulações que - a não ser pelos números - se repetem 
hoje sem quase mudança nenhuma." (Foucault, 1987, p. 234)1. A conclusão de Foucault, em forma de indagação, é esclarecedora: “o pretenso fracasso não faria então parte do funcionamento da prisão?” (Foucault, 1987, p. 239). No caso: a crise não faz parte da funcionalidade da criminologia?

Pavarini demonstra que quando se discorre sobre a criminologia se está a referir uma linguagem eminentemente profissionalizada; se está a apontar um momento histórico em que se estabeleceu a necessidade de demarcar um certo saber como atividade profissional. A condição de possibilidade da profissão criminológica foi a delimitação de “(...) um objeto sobre o qual fixar seu interesse exclusivo.” (PAvarini, 1988, p. 19). Na metáfora proposta por Pavarini, o doente é o prius da ciência médica em relação à categoria doença, mas é certamente um posterius, como objeto de saber, em relação à clínica, pois a reflexão profissional sobre as doenças do corpo e da mente surge depois da hospitalização. Assim, no campo das ciências criminais, em razão da "redução do criminoso ao encarcerado" (PAVARINI, 1988 , p. 19), a criminologia se interessou por uma "patologia" social que, embora preexista ao seu surgimento, é colocada a posteriori como seu objeto.

O saber criminológico surge, portanto, como um conhecimento prático-profissional no interior dos cárceres, direcionado à exploração científica (diagnóstico, classificação e prognóstico) do criminoso reduzido à condição de encarceramento (objeto). Não por outro motivo, os distintos discursos criminológicos giram em torno ou partem da questão carcerária. Cárcere que é a materialização moderna do potestas puniendi; a concretização, em forma jurídica, da violência programada da autoridade constituída contra as liberdades.

\footnotetext{
Segundo Foucault, as formulações que constituem as prisões e que se mantêm constantes seriam: (a) as prisões não diminuem as taxas de criminalidade; (b) a detenção provoca reincidência; (c) a prisão fabrica (direta e indiretamente) a delinquência; e (d) a prisão torna possível a organização de grupos criminosos (organiza, solidariza e hierarquiza). (Foucault, 1987, pp. 234-236)
} 
1.2. Se é válida a hipótese de que a crise da criminologia está organicamente vinculada à sua emergência como prática punitiva, mais especificamente à profissionalização do criminólogo na instituição carcerária (criminologia tecnocrática), é autoexplicativo o fato de os primeiros trabalhos identificados como críticos serem direcionados à desconstrução dos discursos de legitimação da pena e ao desnudamento da instrumentalidade das prisões na Modernidade. Não por outra razão, parte substancial dos estudos identificados com a criminologia crítica orbitam a coluna vertebral formada pelas obras de Rushe e Kirchheimer ("Punição e Estrutura Social”, 1939)2, Foucault ("Vigiar e Punir”, 1975) e Melossi e Pavarini (“Cárcere e Fábrica”, 1977). ${ }^{3}$

O primeiro pressuposto que orienta o ensaio é o de que a criminologia crítica é teoria crítica aplicada ao pensamento criminológico. Para além da coluna vertebral que unificou e orientou as reflexões críticas ao longo do século passado, o ponto de ebulição da criminologia crítica pode ser identificado em distintos textos dos autores do círculo externo da Escola de Frankfurt - Rushe e Kirchheimer, como referido, mas igualmente Neumann (1922) e Fromm (1930; 1931). Em suas primeiras manifestações, portanto, a criminologia crítica se identifica como crítica da economia política do castigo. Em paralelo à crítica da pena e da punição, e com a mesma intensidade, é possível afirmar que o campo criminológico-crítico pressupõe a crítica ao fascismo, desenvolvida de forma mais ampla pelos autores do núcleo interno da Escola de Frankfurt (Adorno, Benjamin, Horkheimer e Marcuse), como chave de interpretação do sistema punitivo. ${ }^{4}$

2 Sobre o trabalho de Rushe e Kirchheimer como fundação da economia política da pena, conferir, exemplificativamente, Giorgi, 2013, pp. 40-59.

3 “'́́ com 'Vigiar e Punir' e 'Cárcere e Fábrica' que o 'como' da punição é colocado nitidamente no foco. Hoje esta perspectiva da punição em relação às tecnologias de poder segue orientando um grande número de trabalhos sobre punição e sociedade." (Simon, 2013, p. 61)

4 Anota Swaaningen que apesar de poucos criminólogos críticos terem trabalhado explicitamente dentro dos marcos da Escola de Frankfurt, as referências implícitas são 
Neste cenário, o segundo pressuposto da crítica é o de que independente do discurso científico no qual a criminologia esteja apoiada (discurso psiquiátrico, estatístico, jurídico ou sociológico), o problema de fundo está radicado na tensão entre liberdade e autoridade, ordem e desordem. A definição dos objetos de estudo, ou seja, a delimitação do horizonte de investigação criminológico (crime, criminoso, criminalidade, reação social, controle social), e a consequente determinação dos métodos [lógico-abstrato, causal-explicativo, construtivismo, materialismo histórico, dialético (Aniyar de Castro/Codino, 2013, pp. 32-33)], dependem, fundamentalmente, de uma eleição prévia que está condicionada à compreensão das demandas por ordem em um determinado cenário econômico e social (Pavarini, 1988, pp. 20-23). Não por outra razão, conforme destaca Zaffaroni, as controvérsias no campo criminológico invariavelmente se estabelecem a partir da maior ou menor vinculação dos modelos teóricos com os poderes constituídos. Assim, a criminologia, como corpo científico, oferece respostas a determinados problemas conforme seu nível de adesão ao poder punitivo, através da justificação ou da denúncia das práticas do sistema penal. A criminologia, portanto, "se relaciona com a luta pelo poder e pela necessidade de ordem.” (Batista, 2011, p. 19)

1.3. A crise da criminologia é seminal e, ao mesmo tempo, é a sua própria permanência. Mas se na aparência a criminologia sempre esteve ultrapassada, o seu esgotamento é confrontado pelo saber

relevantes: a criminologia crítica “(...) [tem] suas raízes nos postulados centrais da teoria crítica, nos quais as perguntas científicas deveriam sempre refletir questões sociais e de que a ciência pode ser um meio para mudança do status quo" (Swaaningen, 2011, p. 05). Ao abordar de forma mais direta os vínculos com a Escola de Frankfurt, notadamente em relação ao marco histórico, cultural e epistemológico da criminologia crítica, Aniyar de Castro e Codino demonstram como a teoria crítica desenvolve uma importante analítica sobre as relações fáticas de poder na qual a dúvida metodológica sobre o seu exercício é central na denúncia do autoritarismo (Aniyar de Castro; Codino, 2013, pp. 239-241). A denúncia da verticalidade e da centralidade do poder é um elemento chave na interpretação dos discursos e das práticas punitivas. 
instrumental que produziu: o saber da criminologia administrada dos realismos de direita e de esquerda que mantém a engrenagem do sistema punitivo em funcionamento. Exatamente por isso a crítica criminológica representou, desde a sua emergência, uma possibilidade de desconstrução e de superação: (a) no movimento negativo da crítica antipositivista (anticriminologia); (b) no movimento positivo das políticas criminais alternativas. Como criminologia da práxis (CARvalho, 2014a; Carvalho, 2014b, pp. 292-297; Carvalho, 2014c, pp. 150-154), as políticas criminais alternativas apontaram a possibilidade de superação da criminologia; sobretudo o abolicionismo: saber transformador e emancipatório - anticriminológico.

A imagem proposta por Stanley Cohen é significativa: a anticriminologia pode ser representada como um “(...) amistoso parasita que cresce ao redor de si mesmo, reproduzindo-se internamente de forma constante, mas que também deve adaptar-se às mudanças em seu organismo hospedeiro (a 'sociedade')" (Cohen, 2009, p. 16).

Uma assertiva de Nils Christie também pode ser tomada como metáfora: a criminologia deve ser abandonada; ao invés de celebrar a abertura, deveríamos comemorar o fechamento dos seus institutos de pesquisa. ${ }^{5}$ Como diretriz, significa dizer que não podemos ser minimamente tolerantes com as estruturas carcerárias, com a construção de "novas vagas prisionais", p. ex., mantra que se repete nos discursos gerencialistas como estratégia para solucionar o problema da superpopulação, apesar de todos saberem, pela experiência de mais de dois séculos, que "criada a vaga, criado o preso".

Ocorre que se o sonho abolicionista, no final dos anos 1970, era palpável, a reação punitivista estabeleceu uma variável insana e a crítica inacabada (unfinished) foi substituída por um encarceramento em massa sem precedentes. Desde as entranhas do Estado penitência,

5 "Talvez não devêssemos ter criminologia. Ao invés de abrir, talvez fosse melhor abolir todos os institutos. Talvez as consequências sociais da criminologia sejam mais duvidosas do que gostamos de imaginar. E eu creio que são.” (Christie, 1977, p. 01) 
a criminologia administrada desenvolveu uma nova musculatura, mantendo-se fiel às fundações positivistas que permanecem inabaladas e altamente funcionais.

Assim, a hipótese que se pretende apresentar é a da urgência da crítica como enfrentamento a todas as formas de encarceramento. Se a criminologia nasce na prisão e se a prisão é a sua crise, a criminologia crítica é, antes de tudo, crítica anticarcerária, crítica anti-institucional. Como anticriminologia, o abolicionismo é a sua principal meta: abolição do cárcere como forma de responsabilidade pelo ato; abolição das instituições que sustentam as prisões e os manicômios; abolição da própria criminologia, entendida como discurso que sustenta a lógica do aprisionamento.

Referindo-se à possibilidade de invenção de uma disciplina para além da criminologia, Cohen afirma que "com exceção do abolicionismo, nada produzido pela anticriminologia, nem a descoberta de novos fatos, nem a criação de um novo modo de entender os antigos fatos, aproxima-se remotamente desse tipo de revolução paradigmática ou disciplinar." (COHEN, 2009, p. 08)

\section{AS ALTERNATIVAS POSSÍVEIS: UM MODELO CRÍTICO DE JUSTIÇA RESTAURATIVA}

2.1. Inúmeras são as razões que justificam a reafirmação das pautas negativas (crítica ao positivismo) e positivas (políticas criminais alternativas) da criminologia crítica. Assim como são inúmeras as razões que tornam urgente a reinvenção e atualização da própria crítica. Nos campos da epistemologia e da ética, dois redirecionamentos nos estudos da criminologia ortodoxa parecem decisivos: (a) a renovação do pensamento positivista a partir dos avanços das criminologias biologicistas, genéticas e neurais (neurocriminologias); e (b) a definição de parâmetros funcionalistas e atuariais para interpretação dos fenômenos criminológicos a partir das análises de riscos individuais e coletivos. $\mathrm{Na}$ esfera político-criminal, a reinvenção do cárcere como 
resposta aos desvios puníveis a partir do final dos anos 1980 e o extremo encarceramento mundial.

Mas se a criminologia crítica redirecionou a lente da criminalidade individual à seletividade do sistema punitivo (da criminalidade à criminalização), notadamente à vulnerabilidade de determinados grupos ao encarceramento, na particularidade latino-americana a crítica percebeu a existência de um problema anterior à seletividade: a letalidade das agências formais e informais do sistema punitivo. Neste ponto provavelmente reside uma das grandes contribuições da criminologia crítica latino-americana às criminologias centrais: a denúncia da letalidade igualmente seletiva das agências oficiais da repressão (direito penal do terror) em harmonia com os grupos paraoficiais (direito penal subterrâneo) - desde análise dos fundadores (ANIYAR de Castro/Codino, 2013, pp. 323-342; Bergalli, 1993; Zaffaroni, 2011) às pesquisas mais recentes (DuArte, 2017; Flauzina, 2006; Pires, 2016; Zaccone, 2015).

$\mathrm{Na}$ realidade latino-americana, em especial a situação brasileira contemporânea, o gravíssimo problema do hiperencarceramento situa-se em uma etapa posterior à do extermínio de determinados grupos sociais e de dissidentes políticos. Por mais que seja trágico afirmar, os enclausurados (encarcerados e manicomizados) no Brasil representam os restos humanos que sobreviveram ao massacre que sofre cotidianamente a juventude brasileira, especialmente a juventude negra, das periferias. ${ }^{6}$ A prisão e o manicômio são os pontos finais de uma política criminal sacrificialista regida pelo racismo sistêmico,

A criminologia negra brasileira não hesita em nominar, de forma muito precisa e adequada, esta política criminal como "genocídio perpetrado contra a juventude negra pelas forças oficiais de Segurança Pública” (Pires, 2016, p. 58). Sobre o tema, conferir, ainda, Flauzina, 2006, pp. 94-139; Pires, 2016, pp. 192-234; Duarte, 2017, pp.169-187; Freitas, 2016, pp. 488-499.

Importante lembrar que esta prática genocida ganhou escala durante a Ditadura CivilMilitar de 1964, não apenas pelo incremento dos crimes de Estado contra os dissidentes políticos, mas também pelo extermínio dos povos originários (CNV, 2014). 
estrutural (CARvalho/Weigert, 2016, p. 17). O diagnóstico de Vilma Reis é tão preciso quanto assustador: "quem não é preso, já foi morto." (ReIs, 2015, p. 05).

Mas apesar de os enclausurados serem sobreviventes da política de extermínio, sua situação não é em nada confortável, pois são submetidos diariamente às mais radicais formas de sofrimento. A realidade prisional (e manicomial) brasileira, retratada em inúmeros relatórios e reportagens é, por si só, a demonstração in natura desta tese (p. ex., HRW, 2018).

Embora o foco deste ensaio não seja a etapa primeira (letalidade) do sistema penal, mas a fase em que a seletividade se materializa em forma de prisionalização, importante destacar que ambas as categorias (letalidade e seletividade) não podem ser dissociadas ou qualquer análise sobre o sistema punitivo latino-americano, em especial o brasileiro, seria incompleta.

Vera Malaguti Batista anota que os criminólogos críticos dos anos 70 não tinham ferramentas para compreender como, no início do século XXI, o neoliberalismo iria trazer “(...) o sistema penal para o epicentro da atuação política.” (BATista, 2011, p. 99) Nesta projeção inimaginável à crítica, na estrutura social contemporânea "a prisão não perdeu o sentido, embora o trabalho vivo, de modo geral, tenha mudado seu espaço no admirável mundo novo. O singular do neoliberalismo foi conjugar o sistema penal com novas tecnologias de controle, de vigilância, de constituição dos bairros pobres do mundo em campos de concentração." (BATista, 2011, p. 99). Não por outra razão, em seus últimos escritos, Pavarini referia uma sociedade em que imperava um modelo de "cárcere sem fábrica." (Pavarini, 2009, pp. 59-80). E é este cenário de encarceramento massivo de pessoas e de grupos vulneráveis que a criminologia crítica é novamente convocada.

2.2. Neste cenário, o maior desafio ainda parece residir na superação da estrutura crime/castigo, baseada no sistema binário de punições e recompensas característico da lei penal moderna, como 
salientava Nils Christie em meados dos anos 1980 (Christie, 1986). Com a simplificação da compreensão dos atos humanos e a limitação da forma de responder aos delitos em uma única opção (pena: prisão), a dificuldade em superar o modelo jurídico-penal moderno é tamanha que qualquer tentativa de estabelecer parâmetros diversos soa como algo inimaginável, uma extravagância ou mesmo uma utopia.

Não por outra razão o abolicionismo penal, com frequência, é visto com ressalvas, independentemente do meio ou da ocasião em que é mencionado ou abordado. Todavia, em nosso entendimento, embora não se confunda com a criminologia crítica, a perspectiva abolicionista permanece como uma das suas mais virtuosas correntes, pois não apenas estabelece um arcabouço crítico consistente, mas também propõe algo concreto e realizável para ocupar o lugar do sistema penal.

Os primeiros trabalhos sobre justiça restaurativa refletiram essa insatisfação crescente com o sistema de justiça criminal tradicional (Hoyle, 2010) e apesar de diversas obras mencionarem a influência do abolicionismo penal, raramente é trabalhado (na literatura de justiça restaurativa) o fato de a corrente abolicionista ser um desenvolvimento da criminologia crítica. No final dos anos 1970, Christie já falava de justiça restaurativa, ainda que sem utilizar explicitamente esse termo (Christie, 1977). As primeiras menções vinculadas à justiça criminal são atribuídas a Albert Eglash, em trabalhos dos anos 1950 (VAn Ness, 2010, pp. 20-21), e a sua utilização mais frequente passa a ocorrer a partir do início dos anos 1990, sobretudo com a publicação de Changing Lenses, de Howard Zehr (1990).

Nesse sentido, pode-se dizer que a justiça restaurativa também é fruto das perspectivas criminológicas críticas (ACHUtTi, 2014; Giamberardino, 2016; Giamberardino, 2015; Pallamolla, 2009, Carvalho, 2014d), embora persista, no país, uma prática conservadora, conforme procuramos desenvolver neste artigo. E é justamente esse desenvolvimento conservador, apesar da sua emergência na crítica, que torna necessária a afirmação um modelo restaurativo crítico, ciente das características do sistema penal e atento às precauções necessárias 
para evitar que a sua lógica colonizadora venha a ser replicada sob o rótulo restaurativo (Achutti, 2014; Aertsen, 2017).

2.3. A obra de Nils Christie é citada em praticamente toda a literatura crítica sobre justiça restaurativa. Responsável por um artigo de importância seminal no final dos anos 1970, o autor estabelece parâmetros que, posteriormente, viriam a se tornar fundamentais para o desenvolvimento do novo modelo.

Ao propor um mecanismo que devolva os conflitos às partes, Christie pensa um sistema constituído por tribunais comunitários (neighbourhood courts), situados o mais próximo possível das comunidades, de forma que os valores locais possam sempre ser levados em consideração. Este modelo de justiça teria uma orientação à vítima, respeitando um procedimento próprio e escalonado, atendendo tanto os interesses das partes (vítimas e ofensores), sem descuidar da comunidade. As cortes locais apresentariam "uma mistura de elementos de tribunais civis e penais, mas com uma forte ênfase nos aspectos civis", e os conflitos seriam previamente analisados por profissionais do direito para evitar punições indevidas (Christie, 1977, pp. 10-11).

Apesar desta análise prévia, o autor considera prejudicial a ampla participação de profissionais na administração dos conflitos. Christie é incisivo: a intervenção de pessoas leigas no trato dos conflitos é de suma importância para evitar que a interferência decorrente da burocratização da justiça criminal e da divisão do trabalho, de forma a interferir negativamente na forma como os casos serão tratados. Os mediadores (ou facilitadores), portanto, não poderiam ser profissionais - salvo em casos excepcionais, para permitir que o sistema tenha vida própria e não corra o risco de desaparecer por falta de voluntários. A preocupação se justifica porque os profissionais, ao alegarem as suas expertises, tendem a manter cada vez mais afastadas as partes.

Conforme Vincenzo Ruggiero, o conhecimento dos profissionais difere do saber acumulado e adquirido no dia a dia das comunidades. Assim, seria plausível admitir que "a quantidade e a natureza das 
informações que possuem os membros do grupo tornará desnecessários conceitos abrangentes como o de "crime"” (Ruggiero, 2011, p. 104). Em consequência, nota-se que resta inviabilizada uma abordagem individualizada dos conflitos na justiça criminal: a burocratização e a divisão do trabalho não permitem que seus funcionários tenham a dimensão das consequências do trabalho que desenvolvem nos gabinetes e nos cartórios, de forma que a responsabilidade no manuseio de cada processo seja sempre diluída. Ao contrário, nos tribunais comunitários os próprios membros da sociedade participarão das deliberações, evitando que a falta de conhecimento sobre o caso seja motivo para eventuais isenções de responsabilidades.

Christie é preciso ao demonstrar a forma simplista como o sistema penal enxerga e lida com o ser humano: ao trabalhar com base em sistemas binários - sim/não, bom/mau, culpado/inocente - a lei penal carrega uma imagem redutora do ser humano e de seus atos (Christie, 1986a, p. 3; Christie, 1986b, pp. 95-96). Com isto, poucas informações são requeridas pelos tribunais, de forma que quanto menos complexo um caso se apresentar, mais fácil será a dinâmica da sua classificação conforme a lei penal: "quanto mais nós olharmos para o ato como um ponto no tempo e não como um processo, mais fácil será a tarefa de classificar o ato na perspectiva da lei penal. Quando menos nós soubermos a respeito de toda a situação, mais simples se torna a operação classificatória." (CHristie, 1986b, p. 6)

O modelo tradicional, ao evitar a compreensão da interação social que dinamizou a ocorrência do evento delituoso e ao buscar responsabilizar apenas o ator imediato pelo ato, naturalmente não conseguirá trabalhar com uma perspectiva coletiva de responsabilidade: a responsabilização (não necessariamente penal ou punitiva) será sempre individual e atomizada, jamais do grupo ou da comunidade em que vive o ofensor. Ao proceder desta forma, a justiça criminal se concentra na classificação do autor do fato e dos fatos em si e passa a acreditar que é possível, em razão desta classificação mesma, considerar casos diferentes como iguais. Para Christie não existem casos iguais: os conflitos 
são tornados iguais a partir dos mecanismos burocráticos e artificiais da lei penal e comprometem a possibilidade de cada caso ser tratado de acordo com as suas peculiaridades. (Christie, 2007, p. 117)

Em decorrência desta criação artificial do caso, conforme diagnóstico de Barata (1998), Christie propõe (a) um modelo de administração de conflitos comunitários, focado na resolução local dos casos, (b) sem a necessidade da intervenção dos profissionais jurídicos e que, fundamentalmente, (c) permita que as partes sejam conhecidas na sua integralidade como seres em constante interação com o seu meio, permitindo que determinadas circunstâncias- consideradas irrelevantes pelas cortes penais - sejam analisadas antes de qualquer tomada de decisão. Objetiva, portanto, evitar ao máximo a intervenção burocrática dos atores do sistema criminal e a delimitação e a concentração do conflito nos parâmetros exclusivos da lei penal.

2.4. É de se notar que Louk Hulsman, talvez o mais conhecido dos abolicionistas penais, seja raramente citado na literatura restaurativa, embora suas críticas sejam tão importantes quanto as de Christie para o estabelecimento de um modelo alternativo de resolução de conflitos.

O autor sugeria que a problematização do conceito de crime era fundamental para o início da construção de um mecanismo alternativo de solução de conflitos. Considerado por Hulsman como "a pedra angular" do sistema penal, o questionamento deste conceito obrigaria "a uma completa renovação de todo o discurso em torno do chamado fenômeno criminal e da reação social que ele suscita." (Hulsman/Celis, 1997, p. 95) Assim, procura apoio "numa noção flexível e possível de ser aplicada a qualquer tipo de conflito interpessoal que demande soluções: a noção de situações problemáticas." (Hulsman/ Celis, 2005, p. 264)

A partir desta noção, novas perspectivas sobre os conflitos seriam criadas, o que possibilitaria às partes a percepção de que uma conduta só é rotulada como crime por ser assim classificada pela lei penal. 
Significa dizer que quando novos olhares são dirigidos ao fenômeno criminal, descolando-o do rótulo (crime) e, em superação, tratando-o a partir de um conceito aberto como uma situação problemática, é deixada "nas mãos dos interessados a possibilidade de escolher o marco de interpretação do acontecimento, assim como a orientação que deve levar a uma possível resposta." (Hulsman/Celis, 2005, p. 264)

O sistema penal inviabiliza uma resolução pensada nas e pelas partes envolvidas também porque, para Hulsman, é caracterizado por uma falta de coesão interna: os diversos subsistemas que o compõem apresentam raros pontos e objetivos em comum, dividem consideravelmente as responsabilidades e obrigações, possuem pouca ou nenhuma coordenação entre si, e frequentemente apresentam diferentes percepções sobre o papel a ser exercido por cada um deles como parte integrante do sistema. Tais características levariam, em consequência, à incontrolabilidade das agências do sistema penal, decorrente desta enorme divisão de trabalho e da substantiva profissionalização dos subsistemas (Hulsman, 1986, p. 64).

Com a intenção explícita de devolver os conflitos às partes, os efeitos esperados seriam (a) a eliminação dos problemas sociais provocados pelo sistema penal, como a produção em série de pessoas culpadas, a estigmatização dos apenados, a marginalização de diversos grupos sociais, dentre outros; e (b) a revitalização da interação social, pois a ausência da estrutura centralizada da justiça criminal abriria espaço para que a sociedade pudesse buscar outros mecanismos - preferencialmente, descentralizados e integrados à comunidade local - para solucionar os seus conflitos (Hulsman/CELIS, 1997).

\section{A INEFICÁCIA DAS ALTERNATIVAS À PRISÃO: A EXPERIÊNCIA BRASILEIRA}

3.1. A importância de vincular as práticas restaurativas com a criminologia crítica e com o abolicionismo penal decorre da potencialidade 
intrínseca que o arquipélago carcerário possui de ampliar a rede de controle, transformando as alternativas em aditivos. A tese é conhecida pelo campo criminológico desde a década de 1970, quando a criminologia crítica apontou os problemas das reformas penais que não retiram a prisão do centro do sistema de justiça e acabam "afinando a malha" ("thinning the mesh") e "ampliando a rede" ("widening the net"), conforme a metáfora sugerida por Cohen em "The Punitive City: notes on the dispersal of social control" (1979). O "afinamento da malha" diria respeito à intensificação de intervenções de controle social de novo tipo e a "expansão da rede" ao submetimento de um número cada vez maior de pessoas ao sistema penal (Zanotelli, 2019, p. 31).

Em 1984, com a reforma do Código Penal, são introduzidas as "penas alternativas" no ordenamento jurídico brasileiro. Embora já fosse evidente, na experiência mundial, o esgotamento da pena de prisão, os reformadores sublinham a necessidade da privação da liberdade como "resposta básica" ao delito, em uma manutenção sem demonização. Para justificar as novas sanções apontam, igualmente, as críticas realizadas pelas Nações Unidas relativas à inadequação do tratamento e à inutilidade dos métodos para redução da reincidência, bem como à violência inerente ao ambiente carcerário, referindo o “(...) o ambivalente propósito de aperfeiçoar a pena de prisão, quando necessária, e de substituí-la, quando aconselhável, por formas diversas de sanção criminal, dotadas de eficiente poder corretivo" (Código Penal, Exposição de Motivos, \29).

No ano de entrada em vigor da nova parte geral do Código Penal brasileiro, sob o título “a ampliação do controle social”, Juarez Cirino

\footnotetext{
"Uma política criminal orientada no sentido de proteger a sociedade terá de restringir a pena privativa da liberdade aos casos de reconhecida necessidade, como meio eficaz de impedir a ação criminógena cada vez maior do cárcere. Esta filosofia importa obviamente na busca de sanções outras para delinquentes sem periculosidade ou crimes menos graves. Não se trata de combater ou condenar a pena privativa da liberdade como resposta penal básica ao delito. Tal como no Brasil, a pena de prisão se encontra no âmago dos sistemas penais de todo o mundo. O que por ora se discute é a sua limitação aos casos de reconhecida necessidade." (Código Penal, Exposição de Motivos, \25)
} 
dos Santos comenta a inserção das penas restritivas de direito e chama a atenção para a armadilha dos mecanismos de desprisionalização: "os substitutivos penais não enfraquecem a prisão, mas a revigoram; não diminuem sua necessidade, mas a reforçam; não anulam sua legitimidade, mas a ratificam: são instituições tentaculares cuja eficácia depende da existência revigorada da prisão, o centro nevrálgico que estende o poder de controle, com a possibilidade do reencarceramento se a expectativa comportamental dos controlados não confirmar o prognóstico dos controladores" (SANTOS, 1985, p. 299).

Ocorre que a crítica aos substitutivos penais não é exclusivamente uma hipótese teórico-acadêmica. Dados empíricos sobre a implementação dos substitutivos penais confirmam a ampliação da rede e o caso brasileiro é exemplar e significativo. Exemplar porque reforça o entendimento de que as reformas não podem ser tecnocráticas; significativo porque aponta alguns problemas que a implementação da Justiça Restaurativa já enfrenta, situação que coloca em dúvida a sua efetividade como alternativa ao cárcere e a sua aplicabilidade como possibilidade de superação do sistema penal.

Analisaremos três experiências que, sob o discurso oficial, teriam impacto na democratização da justiça criminal, através de processos de descarcerização e participação da vítima: (a) a Lei dos Juizados Especiais Criminais (1995); (b) a Lei das Penas Alternativas (1998); e (c) a Lei das Alternativas à Prisão Provisória (2011).

3.2. A Constituição brasileira de 1988 foi bastante inovadora e abriu inúmeras possibilidades para a construção de mecanismos alternativos de abordagem de conflitos. Dois dispositivos constitucionais se destacaram: (a) o art. $5^{\circ}$, XLVI, que estabeleceu um rol não taxativo de sanções penais, em paralelo à prisão ${ }^{8}$; e (b) o art. 98, que prevê a

8 "A lei regulará a individualização da pena e adotará, entre outras, as seguintes: a) privação ou restrição da liberdade; b) perda de bens; c) multa; d) prestação social alternativa; e) suspensão ou interdição de direitos" (art. 5, XLVI, Constituição, grifou-se) 
criação de juizados especiais para resolução de infrações de menor potencial ofensivo.?

Em 1995, foi promulgada a Lei 9.099, que regulamentou o funcionamento dos Juizados Especiais e, na esfera da Justiça Criminal, além de definir as espécies de infrações de sua competência, criou hipóteses diversificadoras que permitiam conciliação com a vítima, nos crimes interpessoais, e acordos com o Ministério Público, nos crimes transindividuais. Apesar de toda a discussão processual penal em torno do caráter obrigatório da ação penal, foram efetivamente implementados os Juizados e as medidas alternativas: (a) composição civil e transação penal, aos crimes de menor potencialidade (crimes cuja pena máxima não ultrapasse dois anos); e (b) suspensão condicional da pena, aos crimes considerados de média lesividade (crimes cuja pena mínima não seja superior a um ano).

Segundo os membros da Comissão, a Lei 9.099/95 cumpriria a função de provocar "uma reviravolta na clássica política criminal fundada na "crença' dissuasória da pena severa (déterrance)" e "(...) testar uma nova via reativa ao delito de pequena e média gravidade, pondo em prática um dos mais avançados programas de 'despenalização' do mundo" (GrinOver et al, 2005, p. 48). Os signos da reforma, marcada pelo otimismo da incorporação de uma "nova mentalidade" pelos atores da Justiça Criminal, foram: desburocratização, informalidade, celeridade, mediação penal, reparação de danos e ressocialização do autor dos fatos (GRINOver et al, 2005, pp. 49-57). Os objetivos centrais eram, fundamentalmente, (a) inserir a vítima em um procedimento baseado no diálogo e na composição do conflito (restituir o conflito à vítima); e (b) reduzir o encarceramento a partir das estratégias de diversificação processual.

\footnotetext{
9 “A União, no Distrito Federal e nos Territórios, e os Estados criarão: I - juizados especiais, providos por juízes togados, ou togados e leigos, competentes para a conciliação, o julgamento e a execução de causas cíveis de menor complexidade e infrações penais de menor potencial ofensivo, mediante os procedimentos oral e sumaríssimo, permitidos, nas hipóteses previstas em lei (...)"(art. 98, Constituição, grifou-se).
} 
Para além de importantes críticas dogmáticas à nova estrutura, sobretudo desde a perspectiva do garantismo penal (Prado, 2006; Coutinho, 2004; Carvalho/Wunderlich, 2002; Carvalho/ WUNDERLICH, 2004), a primeira questão criminológica a ser enfrentada foi a da ineficácia em relação à redução do encarceramento. No ano de criação dos Juizados Especiais Criminais (JECrims) (1995), no Brasil havia 148.760 presos (95 presos por 100.000/hab.) e 78.672 pessoas cumprindo medidas alternativas. Em 2008, último ano em que o DEPEN apresentou relatório de abrangência nacional sobre o cumprimento de penas e medidas alternativas, o encarceramento atingia 439.737 presos (235 presos por 100.000/hab.) e já havia 401.055 pessoas cumprindo medidas alternativas (DEPEN, 2008). Se, no período, o número de encarcerados aumentou 195\%, o acréscimo de medidas alternativas foi de 409\%. Significa dizer que além de não haver redução do encarceramento, foi criado um sistema paralelo de controle.

Importante pesquisa junto aos JECrims nos primeiros anos de sua implantação constatou que a pretensão do novo modelo de desobrigar os Juizados tradicionais das ações de menor potencial ofensivo para que estes pudessem dar maior atenção aos casos de maior gravidade não se concretizou, notadamente porque "passaram a dar conta de um tipo de delituosidade que não chegava às Varas Judiciais, sendo resolvido através de processos informais de 'mediação' nas Delegacias de Polícia ou pelo puro e simples 'engavetamento'”' (Azevedo, 2001, p. 103) Diagnóstico similar ao de Zaffaroni e Batista, que apontam a (re)judicialização de casos que a Justiça Criminal havia, através das categorias da teoria do delito (princípio da insignificância e princípio da adequação social) e dos filtros de ingresso das agências de persecução (Polícia, Ministério Público e Judiciário), descriminalizado de fato: “(...) ressuscitou uma fauna delituosa meio em extinção, aquelas contravenções e aqueles pequenos crimes para os quais já não se dava mais importância, à mingua da burocracia" (ZAFFARONI/ BAtista, 2003, p. 487). 
No que tange à mediação penal e à participação da vítima, o diagnóstico foi igualmente preocupante, notadamente porque o protagonismo das partes na conciliação foi sufocado pela atuação dos profissionais e a reparação dos danos nem sempre foi satisfatória. As rotinas burocráticas do Poder Judiciário acabaram por colonizar o sistema (Azevedo, 2000, p. 196; Wunderlich, 2004, p. 35). Observa Azevedo que era/é considerável o índice de descontentamento das vítimas pois, apesar de presentes fisicamente, permanecem afastadas do processo, inexistindo incentivo para o diálogo conciliatório (AzEvedo, 2005, p. 129; Costa/Aquino/Porto, 2011, p. 46). A burocratização e a decorrente profissionalização da mediação frustraram a possibilidade de emergir uma nova forma de administração dos conflitos e a vítima reassumiu o papel de coadjuvante do processo tradicional.

Ampla e recente investigação do Instituto de Pesquisa Econômica Aplicada (IPEA) e pela Coordenação-Geral de Penas e Medidas Alternativas do DEPEN constatou que "a vítima permanece 'desempoderada' nos JECrims, não sendo um ator relevante na dinâmica desses órgãos judiciais 'especiais', onde praticamente não é ouvida" (IPEA, 2015, p. 88).

3.3. Apesar de as "penas alternativas" terem sido incorporadas no ordenamento jurídico nacional na reforma de 1984, apenas com a entrada em vigor da Lei 9.714/98, as agências do sistema penal estabeleceram um programa de efetividade. Dois fatores parecem ter contribuído para a necessidade da sua implementação: (a) o real aumento da curva de encarceramento ao longo da década de 1990; e (b) a experiência acumulada com os JECrims. 


\section{Evolução da População Carcerária (gráfico 1)}

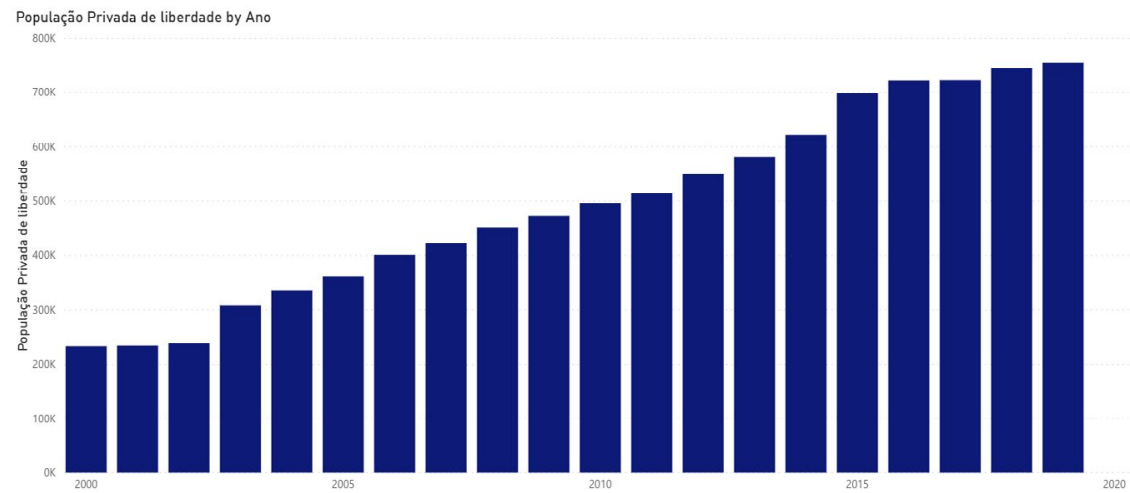

Fonte: DEPEN/MJ (2020)

Como é possível perceber no gráfico, a população carcerária brasileira cresceu de 90.000 presos em 1990 para 232.755 em 2000, atingindo, em dezembro de 2019, 755.254 presos (359,40/100.000). Segundo o Banco Nacional de Monitoramento das Prisões, em junho de 2020 a população prisional brasileira totaliza 867.255 pessoas (CNJ, 2020).

Evolução das Execuções de Penas e Medidas Alternativas (gráfico 2)

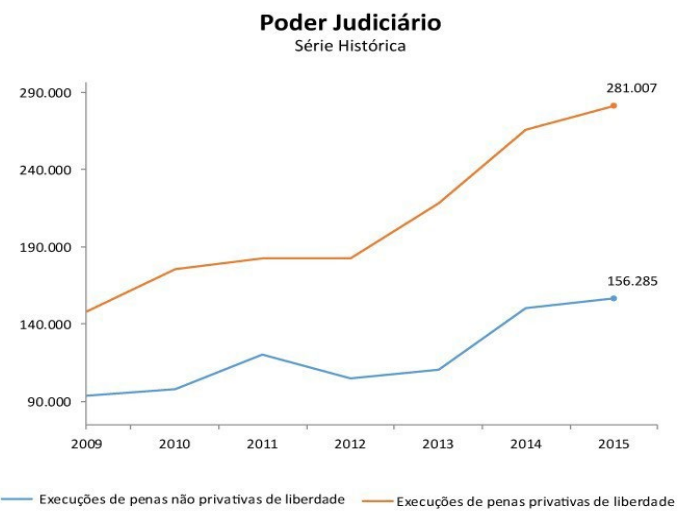

Fonte: CNJ (2017) 
Se em 1995 apenas 1.692 pessoas cumpriam penas alternativas, esse número cresceu exponencialmente após a Lei 9.714/98: 21.560, em 2002; 63.457, em 2006; 88.837, em 2007; e 97.674, em 2008 (DEPEN, 2008) - ano do último relatório apresentado pelo órgão. Segundo o CNJ, em 2015, o Poder Judiciário iniciou a execução de 281.007 penas privativas de liberdade e 156.285 penas alternativas. Conforme a série histórica, mais da metade das novas execuções, na última década, são de condenações a penas alternativas, o que significa dizer que se trata de um sistema não apenas relevante do ponto de vista quantitativo, mas de um aparato paralelo e autônomo ao carcerário.

3.4. A experiência com as medidas alternativas à prisão provisória, a partir da edição da Lei 12.403/11, é provavelmente a mais emblemática. O número de presos provisórios no Brasil sempre foi expressivo, representando em média 40\% da massa carcerária (FBSP, 2016; CNJ, 2020).

Assim, objetivando reduzir este volume de presos sem condenação, o MJ encaminhou projeto de lei que (a) ampliava as possibilidades de fiança, (b) regulamentava a prisão domiciliar e (c) criava medidas cautelares diversas como (c1) o comparecimento periódico em juízo, (c2) a proibição de frequência a determinados lugares, (c3) a proibição de contato com determinadas pessoas, (c4) a proibição de ausentar-se da Comarca ou país, (c5) o recolhimento domiciliar, (c6) a suspensão do exercício de função pública ou de atividade de natureza econômica ou financeira e (c7) o monitoramento eletrônico.

No entanto, conforme noticiado pela imprensa e validado pelos órgãos competentes, após um ano da publicação da Lei 12.403/11, o número de decretos de prisão provisória havia aumentado $6 \%$ no país (Bandeira/Carvalho, 2012; D'Agostino, 2012). 
Dados Encarceramento por Espécie de Prisão em 2018 (gráfico 3)

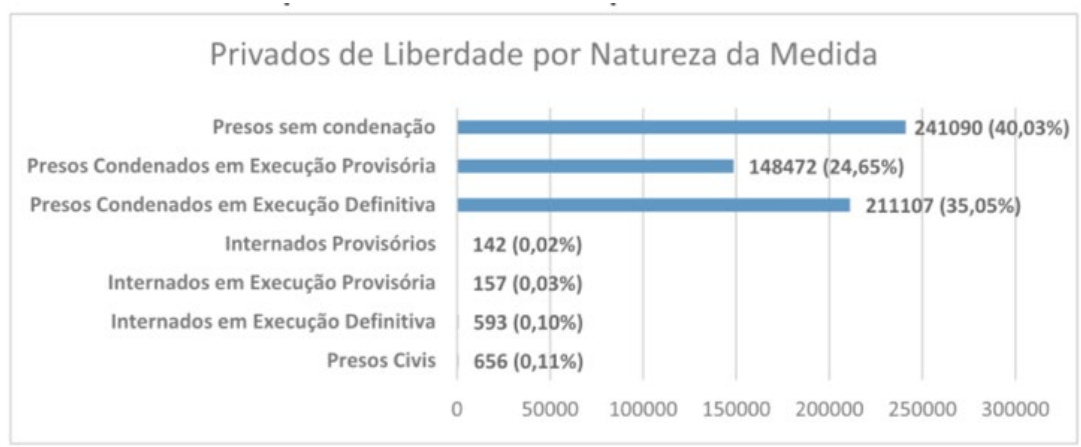

Fonte: $\mathrm{CNJ}(2018)$

Atualmente, dados detalhados pelo CNJ demonstram ser o problema ainda mais complexo. O monitoramento realizado em julho de 2020 indicava que $43,70 \%$ dos presos eram provisórios. No entanto, do total de presos condenados, 22,46\% encontravam-se em execução provisória e apenas 33,40\% em execução definitiva. Significa dizer, portanto, que $66,16 \%$ das pessoas encarceradas atualmente no Brasil não tiveram uma sentença final resolutiva de mérito.

O Brasil repete, portanto, a experiência internacional da ampliação da rede de punitividade através dos substitutivos penais e, com as suas particularidades, confirma a hipótese histórica da criminologia crítica (Pallamolla, 2009, pp. 29-33). Por esta razão, entendemos que a criminologia crítica, como crítica anticarcerária, não pode restar limitada ao discurso da diminuição do encarceramento.

Logicamente a redução do encarceramento é uma diretriz fundamental e urgente. No entanto, na maioria das vezes, o resultado é exclusivamente o da ampliação da rede sem reduzir a potência do cárcere, como de fato ocorreu no Brasil. Neste cenário, o elogio dos substitutivos obstaculiza o debate sério sobre a descriminalização, a despenalização e a própria Justiça Restaurativa, como mecanismo de resolução alternativa (não-burocrática, não-institucional, não-profissionalizada) de conflitos. 


\section{OS MOTIVOS DO FRACASSO DAS ALTERNATIVAS À PRISÃO NO BRASIL E A SUA PROJEÇÃO NA IMPLEMENTAÇÃO DA JUSTIÇA RESTAURATIVA}

4.1. Em razão da verificabilidade empírica da inefetividade das alternativas penais no Brasil, duas perguntas parecem relevantes: (a) por que os substitutivos se transformaram em aditivos ao cárcere? (b) o que fazer para que esta experiência frustrada não contamine o projeto restaurativo?

Como foi possível perceber, a implementação das penas e medidas alternativas no Brasil foi iniciativa dos Poderes Legislativo e Executivo. Os projetos foram respostas às suas próprias ações que, ao longo dos anos 90, geraram uma hipertrofia no sistema penitenciário em decorrência da ampliação do número de tipos incriminadores, do aumento de penas, de estabelecimento de novas hipóteses de prisões provisórias e das limitações à progressão de regime. No entanto, inúmeras pesquisas têm demonstrado que a principal resistência à descarcerização e à diversificação vem do Poder Judiciário.

No último relatório nacional sobre as penas alternativas, DEPEN e IPEA são explícitos ao apontar, dentre os principais óbices para a adoção das medidas descarcerizadoras, a atuação dos juízes, sobretudo pelo uso excessivo das prisões cautelares, o arbítrio na dosimetria das penas e a resistência na aplicação das PMAs (IPEA, 2015; ILANUD, 2006). O fenômeno da adesão subjetiva da magistratura nacional ao punitivismo tem sido amplamente debatido no campo acadêmico nas últimas décadas (Azevedo, 2014; Carvalho, 2010a; Carvalho, 2015; Carvalho/Weigert, 2012; Prado/Casara, 2010; Sinhoreto, 2014), e a validade da assertiva pode ser verificada em reportagens (DOMENICI, 2018; Rodas, 2018; Stabile, 20160), relatórios oficiais e do terceiro setor (DPERJ, 2018; Pastoral Carcerária, 2016; Justiça Global, 2016) e, inclusive, nos levantamentos das próprias associações de classe (AMB, 2015; Vianna, 2018). A conclusão, portanto, é a de que "não 
raro o juiz/intérprete esvazia o conteúdo libertador do dispositivo legal desencarcerador ao apresentar respostas estatais que prestigiam o cárcere em detrimento de alternativas menos danosas à dignidade humana" (Prado/CASARA, 2010, p. 355).

A adesão subjetiva ao punitivismo deriva, sobretudo, da tradição autoritária e da formação inquisitorial dos atores do sistema penal brasileiro (Carvalho, 2010a; Coutinho; 1994; Prado, 1999). Se a perspectiva punitivista dinamiza o encarceramento e a ampliação da rede do controle penal, a mentalidade inquisitorial marca o protagonismo judicial nos procedimentos criminais. Apesar da vedação constitucional da atuação de ofício, sobretudo com a delimitação da titularidade da ação penal no Ministério Público, a condução do processo penal no Brasil é uma atividade eminentemente judicial, notadamente na gestão da prova. O caráter presidencialista do processo penal brasileiro coloca o juiz no centro da resolução dos conflitos, muitas vezes substituindo as partes. A postura inquisitorial, por apresentar um déficit democrático evidente, não apenas favorece o punitivismo, como obstaculiza as alternativas, visto que, no paradigma restaurativo, os protagonistas na resolução dos seus conflitos devem ser as partes.

A mais recente e abrangente pesquisa nacional sobre Justiça Restaurativa aponta nessa direção: o papel predominantemente judicial nas práticas restaurativas. Segundo o relatório dirigido por Vera Andrade, a tradução nacional do paradigma restaurativo dá origem a uma Justiça Restaurativa Judicial (ANDRADE, 2018, p. 113)..$^{10}$ Mais: o

${ }^{10}$ Importante destacar que este protagonismo judicial, diferentemente do que ocorre no processo penal tradicional e nos Juizados Especiais Criminais, não ocorre na mediação direta entre as partes, isto porque esta atividade é restrita aos facilitadores. No entanto, apesar de não existir esta intervenção direta no círculo propriamente dito, o predomínio dos atores judiciais ocorre em duas dimensões: (a) administrativa, na implementação e na gestão dos programas; e (b) processual, na definição dos critérios de participação, no encaminhamento de autores do fato e vítimas aos programas, na determinação do alcance desta participação e na fixação de condicionantes para alcançar "benefícios" penais ou processuais penais (p. ex., exigência de confissão para redução ou extinção de pena). 
protagonismo não é apenas o do Poder Judiciário, mas de sujeitos específicos que implementam práticas restaurativas como projetos pessoais: "confirmou-se, pois, a hipótese do protagonismo exercido pelo Poder Judiciário, seus atores e órgãos conexos (juízes, desembargadores, psicólogos, assistentes sociais, equipes técnicas, sistema de justiça, Ministério da Justiça, Secretaria de Reforma do Judiciário, Conselho Nacional de Justiça) no Brasil, ao qual se deve acrescentar o adjetivo personalizado. Trata-se de um protagonismo personalizado, porque liderado, sobretudo, por pessoas e equipes específicas, e das quais têm dependido, em grande medida, a própria sustentabilidade dos programas" (ANDRADE, 2018, p. 153). O diagnóstico realizado pelo CNJ já havia sido antecipado e confirmado por pesquisas acadêmicas do mesmo período que apontam um profundo déficit democrático na implementação das práticas restaurativas no Brasil, exatamente em decorrência da sua adaptação à cultura jurídica tradicional de matriz inquisitorial protagonizada por juízes e demais profissionais (Pallamolla, 2017).

4.2. Outros dois episódios recentes merecem menção pela verossimilhança com os casos apresentados e por reforçarem o argumento principal do ensaio. O primeiro é relativo à publicação, em agosto de 2019, dos resultados da pesquisa coordenada pelo Instituto de Defesa do Direito de Defesa (IDDD), sobre a implementação das audiências de custódia no Brasil. Segundo o instituto, os resultados apontaram que as audiências de custódia precisam ser urgentemente melhoradas para reduzir o encarceramento e garantir a investigação de casos de violência policial (IDDD, 2019).

Após iniciativa do Conselho Nacional de Justiça (CNJ), que decidiu implementar pela via judicial a garantia prevista no Pacto Internacional sobre Direitos Civis e Políticos e do Pacto de São José da Costa Rica, foi publicada a Resolução n. 213/2015, que regulamenta o funcionamento das audiências de custódia. Referidos tratados preveem que "qualquer pessoa presa deve ser apresentada, sem demora, 
a uma autoridade judicial. Também afirmam que a prisão preventiva de quem espera julgamento deve ser sempre a exceção, e não a regra." (IDDD, 2019b, p. 9).

$\mathrm{Na}$ audiência de custódia é garantido o encontro entre o acusado e o juiz, na presença de defesa e representante do Ministério Público, em um período de até 24 horas da prisão. No ato, o juiz avaliaria "se a detenção atendeu aos requisitos legais, se a pessoa presa foi vítima de maus-tratos ou tortura e, ainda, se precisa responder ao processo em prisão preventiva, caso aplicáveis as hipóteses previstas no $\mathrm{CPP}$ (Código de Processo Penal)" (IDDD, 2019b, p. 9). A audiência de custódia representaria "um espaço privilegiado que permite a escuta segura da pessoa presa - algo que antes acontecia apenas na audiência de instrução, meses depois da prisão.” (IDDD, 2019b, p. 10). Ademais, objetiva averiguar atos de maus-tratos e de tortura por autoridades públicas, além de reduzir os índices de pessoas que respondem ao processo em prisão preventiva em razão da avaliação da legalidade e da necessidade da medida cautelar.

Todavia, de acordo com o relatório, a liberdade provisória irrestrita (sem a aplicação de qualquer medida cautelar diversa da prisão) tem representado uma exceção à regra, pois das 2.584 decisões acessadas pelos pesquisadores constatou-se que em apenas 23 casos (ou 0,89\%) houve concessão (IDDD, 2019a, p. 92). Conforme os analistas, restou claro que oito anos após a entrada em vigor das medidas cautelares diversas da prisão, a liberdade sob condições (cumprimento de alguma obrigação) tornou-se "uma alternativa à própria liberdade, e não à sua privação, como era o intuito da lei." (IDDD, 2019a, p. 97). Como os demais institutos descarcerizadores, as medidas cautelares alternativas previstas na Lei 12.403/11 não diminuíram o número de pessoas presas provisoriamente, mas o número de pessoas livres sobre as quais não recaia qualquer controle do sistema penal (IDDD, 2019a, p. 97). Já os casos de decretação de prisão preventiva nas audiências de custódia, em contrapartida, representaram 57\% do total (IDDD, 2019b, p. 20), situação que nos parece ser um evidente contrassenso. 
O segundo episódio é relativo à posição da Associação dos Magistrados Brasileiros (AMB) sobre a implementação do juiz de garantias pela Lei 13.964/19. ${ }^{11}$ Sancionada a Lei em 25 de dezembro de 2019, dois dias depois, a AMB emitiu nota pública (AMB, 2019a) em reação à mudança na estrutura do sistema de investigação preliminar no processo penal brasileiro e, ato contínuo, no mesmo dia, em parceria com a Associação dos Juízes Federais (AJUFE), ajuizou Ação Direta de Inconstitucionalidade (ADI 6298) no Supremo Tribunal Federal (STF), questionando os dispositivos dos artigos 3-A, 3-B, 3-C, 3-D, 3-E e 3-F, introduzidos pelo artigo $3^{\circ}$ (AMB, 2019b). Em apreciação do pedido cautelar, o Min. Dias Toffoli concedeu liminar, em 22 de janeiro de 2020, adiando a implementação do juiz de garantias pelos Tribunais por 180 dias (STF, 2020).

O objetivo da implementação da figura do juiz de garantias na fase preliminar, pré-processual, é o de aumentar o grau de imparcialidade do juiz sentenciante, além de dar maior efetividade às garantias e aos direitos do investigado. O instituto não é novo no direito comparado, estando presente em inúmeros sistemas processuais de tradição romano-germânica, como se percebe nas legislações chilena, italiana, espanhola e portuguesa. Trata-se de um instrumento histórico de aperfeiçoamento e fortalecimento do sistema acusatório nas estruturas do processo penal dos Estados democráticos de direito. Em realidade, conforme a modelagem constitucional brasileira, o anômalo é convivermos com um sistema de inquérito, típico das formas inquisitoriais. No entanto, conforme aponta a AMB ao defender a manutenção da estrutura do Código de 1940, a magistratura nacional já vem desempenhando o papel institucional de "controlar a legalidade do procedimento inquisitivo e salvaguardar os direitos e garantias fundamentais." (AMB, 2019a).

11 Importante ressalvar a posição da Associação dos Juízes para a Democracia (AJD) que não apenas posicionou-se favoravelmente à mudança legal, mas inclusive requereu ingresso como amicus curiae na referida ADI para defender a constitucionalidade da reforma (AJD, 2019; AJD, 2020). 
4.3. Os dois episódios, lidos em conjunto com os três casos analisados, parecem confirmar o diagnóstico (hipótese do ensaio) de que a formação (e a ação) autoritária do Poder Judiciário brasileiro tem impedido a eficácia dos institutos descarcerizadores. Os episódicos esforços dos Poderes Executivo e Legislativo na redução do controle penal são inviabilizados, no cotidiano forense, pelos atores judiciais, que mantêm a privação de liberdade como o centro gravitacional das suas formas de pensar e de agir.

Quaisquer avanços que visem ampliar os espaços de liberdade e/ ou conferir maior transparência às decisões judiciais, sobretudo àquelas que podem resultar em privação de liberdade, esbarram nos efeitos reais provocados pela lógica inquisitorial. Assim, são entraves para a implementação de modelos alternativos de resolução de conflitos não apenas a estrutura normativa inquisitória do processo penal brasileiro, mas (sobretudo) a formação autoritária do Poder Judiciário, enraizada na centralização vertical das decisões, na burocratização dos procedimentos e na profissionalização dos atores, comprometendo a superação dos paradigmas retributivo e correcionalista em direção ao paradigma restaurativo.

Todos esses elementos apontam para critérios de resolutividade de conflitos concentrados em práticas judiciais preponderantemente paternalistas, isto é, um modelo estruturado em procedimentos institucionais no qual o representante estatal (juiz) protagoniza a cena e decide em nome ou apesar das partes. A forma tradicional de abordagem é paternalista porque toma os indivíduos envolvidos em situações problemáticas como incapazes de olhar, interpretar e superar os seus conflitos. Assim, ao mesmo tempo desresponsabiliza e incapacita as pessoas de se tornarem sujeitos da sua própria história.

Percebe-se que a tradição brasileira do monopólio institucional da resolução do conflito não foi abandonada na "domesticação" da Justiça Restaurativa. O “(...) protagonismo tem resultado em acúmulo, e não redistribuição, de poder (com pessoas e comunidades) nas mãos do Judiciário" (CNJ, 2018, p. 156), o que contraria os pilares 
estruturantes do paradigma restaurativo, pois com isso não se inverte o processo de apropriação estatal de um conflito que é, em primeira e última análise, das vítimas.

\section{CONSIDERAÇÕES FINAIS}

5.1. A hipótese que orientou o ensaio foi a da urgência da crítica criminológica como enfrentamento de todas as formas de encarceramento. Pensamos, portanto, que a crítica anticarcerária deve atingir, com a mesma intensidade, a rede ampliada que se forma ao redor do arquipélago prisional dinamizada pelos substitutivos penais. Assim como não se deve ter qualquer tolerância com as estruturas prisionais, pela violência intrínseca que produzem, os substitutivos devem ser submetidos à crítica de igual intensidade pela sua capacidade de reforçar o encarceramento. A experiência brasileira não apenas comprova como densifica o ceticismo da criminologia crítica em relação às alternativas penais, em um diagnóstico de quase meio século.

O acúmulo teórico e a vivência empírica em relação aos substitutivos penais, notadamente no caso brasileiro, fornecem elementos importantes para o traçado de algumas rotas de fuga das armadilhas que representam o "afinamento da malha" ("thinning the mesh") e a "ampliação da rede" ("widening the net") no contexto das práticas restaurativas. Como prática anticriminológica (abolicionista), entendemos que o paradigma restaurativo deve ser orientado pelas críticas anticarcerária e anti-institucional, isto é, por uma perspectiva de ação baseada em princípios antiburocratizantes e antiprofissionalizantes.

Assim, o modelo judicial de Justiça Restaurativa Judicial que foi domesticado (traduzido) no Brasil, conforme apontado pelo próprio $\mathrm{CNJ}$, já dá indícios da reprodução dos vícios históricos que inviabilizaram as demais iniciativas descarcerizadoras: Lei 9.099/95, Lei 9.714/98 e Lei 12.403/11. O centralismo burocrático e o idealismo personalizado são sintomas desses vícios e tendem a, vez mais, criar um modelo paralelo 
de controle sem arranhar a curva de encarceramento e sem implicar os sujeitos do conflito (autor e vítima) na busca da resolução.

Neste cenário, é precisa a orientação de Ruggiero no sentido de que a perspectiva abolicionista de abandono da organização cultural e social (e da mentalidade inquisitorial, acrescentamos) da Justiça Criminal deve ser orientada fundamentalmente para as partes envolvidas, reforçando a ideia de que as diferentes situações criminalizadas não podem ser classificadas como equivalentes, modelo-padrão do processo criminal tradicional. Nesta perspectiva, o contexto altamente formal e burocrático da Justiça Criminal deve ser substituído pela descentralização de administração de conflitos, de forma a permitir uma maior flexibilização da compreensão da situação problemática e, assim, criar condições para que sejam arquitetados ambientes saudáveis para uma disputa participativa entre os envolvidos (Ruggiero, 2011, p. 102).

5.2. Em conclusão, pensando sobretudo nas particularidades da experiência brasileira (ACHUTTi, 2014), entendemos urgente e necessário a densificação de um modelo restaurativo que observe os seguintes eixos estruturantes:

(primeiro) autonomia dos núcleos ou serviços de Justiça Restaurativa, instituídos a partir de uma nova linguagem, como forma de minimizar as possibilidades de colonização das práticas pela lógica burocrática da Justiça Criminal e inquisitorial do processo penal tradicional;

(segundo) singularização dos casos, evitando classificações legais apriorísticas (ilícito civil vs. ilícito penal) e a massificação dos conflitos;

(terceiro) participação ativa das partes na decisão sobre o encaminhamento dos casos e na resolução dos conflitos, na condição de principais interessados e como estímulo de uma tomada de decisão coletiva;

(quarto) refutação de estereótipos que possam ser atribuídos às partes, evitando os efeitos indesejados da revitimização e da estigmatização do autor do fato; 
(quinto) obrigatoriedade da presença de profissionais metajurídicos na condução dos procedimentos, ainda que paralelamente aos operadores do direito enquanto não houver alteração legislativa, a fim de agregar interdisciplinaridade e comunitarismo na gestão do conflito;

(sexto) atenção à satisfação das necessidades dos envolvidos (vítima, ofensor e comunidade), com o comprometimento coletivo para resolução do problema e cumprimento do acordo eventualmente realizado; e

(sétimo) subsidiariedade da relação com a Justiça Criminal e da participação dos profissionais do direito, enquanto houver obrigatoriedade legal, de maneira a reduzir a contaminação pela mentalidade autoritária do sistema tradicional, prevenir que as práticas restaurativas não sejam mero apêndice do controle punitivo e evitar a potência expansionista do arquipélago carcerário.

Neste sentido, imaginamos um modelo de Justiça Restaurativa que seja, antes e acima de tudo, fundado na crítica criminológica e, em consequência, resista à colonização própria da programação do sistema punitivo. Exatamente por esta razão, entendemos necessária a incorporação das dimensões teóricas e práticas fornecidas pelo abolicionismo penal de forma a colocar as possibilidades restaurativas no centro das discussões anticarcerárias. Implica, pois, superar a lógica punitivista na qual as alternativas são sempre instrumentalizadas como subsistemas de um modelo protagonizado pelo cárcere.

\section{REFERÊNCIAS}

ACHUTTI, Daniel. Justiça Restaurativa e Abolicionismo Penal. São Paulo: Saraiva, 2014.

AERTSEN, Ivo; PALI, Brunilda (eds.). Critical Restorative Justice. Oxford/Portland: Hart Publishing, 2017.

AJD-Associação Juízes para a Democracia. AJD requer ao STF ingresso como Amicus Curiae em ADIs que discutem a figura do juiz 
de Garantias, AJD, 25/02/2020 [disponível em https://www.ajd.org.br/ noticias/2526-ajd-requer-ao-stf-ingresso-como-amicus-curiae-em-adis-que-discutem-a-figura-do-juiz-de-garantias].

AJD-Associação Juízes para a Democracia. AJD manifesta seu apoio à adoção do instituto do juiz de garantias, AJD, 28/12/2019 [disponível em https://www.ajd.org.br/noticias/2517-ajd-apoio-juiz-garantias].

AMB-Associação dos Magistrados do Brasil. Pesquisa AMB 2015: a AMB quer ouvir você. Rio de Janeiro: AMB, 2015.

AMB-Associação dos Magistrados do Brasil. Nota Pública - Juiz de garantias, AMB, 27/12/2019a [disponível em https://www.amb.com.br/ nota-publica-juiz-de-garantias/?doing_wp_cron=1591584934.675642013 5498046875000]

AMB-Associação dos Magistrados do Brasil. AMB e Ajufe ingressam com ADI no STF contra "juiz das garantias", AMB, 27/12/2019b [disponível em https://www.amb.com.br/amb-e-ajufe-ingressam-com-adi-no-stf-contra-juiz-das-garantias/?doing_wp_cron=1591708091.43194 38934326171875000]

ANDRADE, Vera (coord). Pilotando a Justiça Restaurativa. Brasília: CNJ, 2018.

ANIYAR DE CASTRO, Lola; CODINO, Rodrigo. Manual de Criminologia Sociopolitica. Buenos Aires: Ediar, 2013.

AZEVEDO, Rodrigo G. Sociologia da Administração da Justiça Penal. In: Lima, Renato S. et al (orgs). Crime, Polícia e Justiça no Brasil. São Paulo: Contexto, 2014.

BANDEIRA, Luiz; CARVALHO, Daniel. Apesar da nova lei, cresce o total de presos ainda não julgados no Brasil. Jornal Folha de São Paulo, 08/12/2012 [disponível em https://m.folha.uol.com.br/cotidiano/2012/12/ 1198074-apesar-de-nova-lei-cresce-total-de-presos-ainda-nao-julgados-no-brasil.shtml]

BARATTA, Alessandro. La Vida y el Laboratório del Derecho: a propósito de la imputación de responsabilidad en el proceso penal. Doxa, v. 05, 1998.

BATISTA, Vera Malaguti. Introdução Crítica à Criminologia Brasileira. Rio de Janeiro: Revan, 2011. 
BERGALLI, Roberto. Fallacia Garantista nella Cultura Giuridico-Penale di Lingua Ispanica. In: GIAMFORMAGGIO, Letizia (coord.). Le Ragioni del Garantismo: discutindo com Luigi Ferrajoli. Milano Giappichelli, 1993.

CARVALHO, Salo; WEIGERT, Mariana A. B. As Alternativas às Penas e às Medidas Socioeducativas: estudo comparado entre distintos modelos de controle social punitivo. Sequência, n. 64, 2012.

CARVALHO, Salo; WEIGERT, Mariana de Assis Brasil. Sofrimento e Clausura no Brasil Contemporâneo: estudos críticos sobre fundamentos e alternativas às penas e medidas de segurança. Florianópolis: Empório do Direito, 2016.

CARVALHO, Salo; WUNDERLICH, Alexandre (orgs.). Diálogos Sobre a Justiça Dialogal: teses e antíteses sobre os processos de informalização e privatização da justiça penal. Rio de Janeiro: Lumen Juris, 2002.

CARVAlHO, Salo; Wunderlich, Alexandre (orgs.). Novos Diálogos Sobre os Juizados Especiais Criminais. Rio de Janeiro: Lumen Juris, 2004.

CARVAlHO, Salo. A Política Criminal de Drogas no Brasil. 7. ed. São Paulo: Saraiva, 2014c.

CARVAlHO, Salo. Antimanual de Criminologia. 6. ed. São Paulo: Saraiva, 2015.

CARVALHO, Salo. Criminologia Crítica: dimensões, significados e perspectivas atuais. Revista Brasileira de Ciências Criminais, ano 21, v. $104,2014 b$.

CARVALHO, Salo. O 'Gerencialismo Gauche' e a Crítica Criminológica que não teme dizer seu nome. Revista Direitos e Garantias Fundamentais, v. 15, n. 1, 2014a.

CARVALHO, Salo. O Encarceramento Seletivo da Juventude Negra Brasileira: a decisiva contribuição do Poder Judiciário. Revista da Faculdade de Direito da UFMG, n. 67, v. 2, 2015.

CARvalho, Salo. O Papel dos Atores do Sistema Penal na Era do Grande Encarceramento. Rio de Janeiro: Lumen Juris, 2010a.

CARVALHO, Salo. Sobre as Possibilidades de um Modelo Crítico de Justiça Restaurativa. Sistema Penal e Violência, v. 6, n. 1, 2014d. 
CARVALHO, Salo. Substitutivos Penais na Era do Grande Encarceramento. In: Abramovay, Pedro V.; Batista, Vera Malaguti (orgs.). Depois do Grande Encarceramento. Rio de Janeiro: Revan, 2010b.

CHRISTIE, Nils. Conflict as Property. The British Journal of Criminology, v. 17, n. 01, 1977.

CHRISTIE, Nils. Crime Control as Drama. Journal of Law and Society, v. 13, n. 1, 1986.

CHRISTIE, Nils. Images of Man in Modern Penal Law. Contemporary Crises, v. 10, n. 1, 1986.

CHRISTIE, Nils. Restorative Justice - answers to deficits in modernity? In: Downes, David; Rock, Paul; Chinkin, Christine; Gearty, Conor (eds.). Crime, Social Control and Human Rights: from moral panics to states of denial. Essays in honour of Stanley Cohen. Londres: Willan Publishing, 2007.

CNJ-Conselho Nacional de Justiça. Banco Nacional de Monitoramento de Prisões - BNMP 2.0: Cadastro Nacional de Presos. Brasília: CNJ, 2018 [disponível em https://www.cnj.jus.br/sistema-carcerario/cadastro-nacional-de-presos-bnmp-2-0/]

CNJ-Conselho Nacional de Justiça. Banco Nacional de Monitoramento de Prisões - BNMP 2.0: Cadastro Nacional de Presos. Brasília: CNJ, 2020. [disponível em https://www.portalbnmp.cnj.jus/br/, acesso em 04 de junho de 2020 .

CNV-Comissão Nacional da Verdade. Relatório. v. 02. Brasília: CNV, 2014. COHEN, Stanley. Against Criminology. London: Transaction Publishers, 2009.

COUTINHO, Jacinto Nélson de Miranda. Manifesto contra os Juizados Especiais Criminais: uma leitura de certa 'efetivação' constitucional. In: CARVALHO, Salo; WUNDERLICH, Alexandre (orgs.). Novos Diálogos Sobre os Juizados Especiais Criminais. Rio de Janeiro: Lumen Juris, 2004.

COUTINHO, Jacinto Nélson de Miranda. O Papel do Novo Juiz no Processo Penal. Direito Alternativo: anais do evento comemorativo do Sesquicentenário do Instituto dos Advogados Brasileiros. Rio de Janeiro: IAB, 1994. 
D’AGOSTINO, Rosanne. Lei da nova fiança completa 1 ano, mas não reduz lotação das cadeias, G1, 02/07/2012 [disponível em http://g1.globo. com/brasil/noticia/2012/07/lei-da-nova-fianca-completa-1-ano-mas-nao-reduz-lotacao-de-cadeias.html]

DE FOLTER, Rolf S. On the Methodological Foundation of the Abolitionist Approach to the Criminal Justice System: a comparison of the ideas of Hulsman, Mathiesen and Foucault. Contemporary Crises, v. 10, n. 1, 1986.

DEPEN-Departamento Penitenciário Nacional. Evolução Histórica das Penas e Medidas Alternativas (PMAs) no Brasil. Brasília: DEPN/ MJ, 2008.

DOMENICI, Thiago; Barcelos, Iuri. Como a Justiça paulista sentenciou negros e brancos para tráfico, El País, 06/12/2018 [disponível em https:// brasil.elpais.com/brasil/2018/12/05/politica/1544039812_987576.html].

DPERJ-Defensoria Pública do Estado do Rio de Janeiro. Relatório Final: pesquisa sobre as sentenças judiciais por tráfico de drogas na cidade e região metropolitana do Rio de Janeiro. Rio de Janeiro: DPERJ, 2018.

DUARTE, Evandro Piza. Ensaio Sobre a Hipótese Colonial: racismo e sistema penal no Brasil. In: CARVALHO, Salo; DUARTE, Evandro Piza. Criminologia do Preconceito: racismo e homofobia nas Ciências Criminais. São Paulo: Saraiva, 2017.

FBSP-Fórum Brasileiro de Segurança Pública. Anuário Brasileiro de Segurança Pública. São Paulo: FBSP, 2016.

FLAUZINA, Ana. Corpo Negro Caído no Chão: o sistema penal e o projeto genocida do Estado Brasileiro. Dissertação de Mestrado, Programa de Pós-Graduação em Direito da Universidade de Brasília, Brasília, 2006. FOUCAULT, Michel. Vigiar e Punir: história da violência nas prisões. 8. ed. Petrópolis: Vozes, 1987.

FREITAS, Felipe. Novas Perguntas para a Criminologia Brasileira: poder, racismo e direito no centro da roda. Cadernos do CEAS, n. 238, 2016.

FROMM, Erich. On the Psychology of Criminal Justice and the Punitive Society (1931). In: ANDERSON, Kevin; QUINNEY, Richard (eds.). Erich Fromm and Critical Criminology: beyond the punitive society. Chicago: University of Illinois Press, 2000. 
FROMM, Erich. The State as Educator: on the Psychology of Criminal Justice (1930). In ANDERSON, Kevin; QUINNEY, Richard (eds.). Erich Fromm and Critical Criminology: beyond the punitive society. Chicago: University of Illinois Press, 2000.

giamberardino, André R. Crítica da Pena e Justiça Restaurativa: a censura para além da punição. Florianópolis: Empório do Direito, 2016.

GIAMBERARDINO, André. Proposições sobre o Presente e o Futuro da Criminologia Crítica no Brasil. Revista Eletrônica Direito e Sociedade, v. 3, n. 1, 2015.

HOYLE, Carolyn. The Case for Restorative Justice. In CUNNEEN, Chris; HOYLE, Carolyn. Debating Restorative Justice. Oxford/Portland: Hart Publishing, 2010.

HRW-Human Rights Watch. Relatório Mundial: Brasil (resumo do país), WRW, 2018 [disponível em https://www.hrw.org/pt/world-report/2018/ country-chapters/313303].

HULSMAN, Louk; Celis, Jacqueline Bernat de. A Aposta por uma Teoria da Abolição do Sistema Penal. Revista Verve, n. 8, 2005.

HUlsman, Louk; CELIS, Jacqueline Bernat de. Penas Perdidas: o sistema penal em questão. 2. ed. Niterói: Luam, 1997.

HULSMAN, Louk. Critical Criminology and the Concept of Crime. Contemporary Crises, v. 10, n. 1, 1986.

IDDD-Instituto de Defesa do Direito de Defesa. O Fim da Liberdade: a urgência em recuperar o sentido e a efetividade das audiências de custódia (relatório nacional). São Paulo: IDDD, 2019a.

IDDD-Instituto de Defesa do Direito de Defesa. O Fim da Liberdade: a urgência em recuperar o sentido e a efetividade das audiências de custódia (sumário executivo). São Paulo: IDDD, $2019 b$.

ILANUD-Instituto Latino Americano das Nações Unidas para Prevenção do Delito e Tratamento do Delinquente. Levantamento Nacional sobre Execução de Penas Alternativas: Relatório Final de Pesquisa. Brasília: ILANUD, 2004.

JUSTIÇA GLOBAL. Mecanismo Estadual de Prevenção e Combate à Tortura do Rio de Janeiro. Quando a Liberdade é Exceção: A situação das 
pessoas presas sem condenação no Rio de Janeiro. Rio de Janeiro: Global/ MecanismoRJ, 2016.

NEUMANN, Franz. Rechtsphilosophische Einleitung zu einer Abhandlung über das Verhältnis von Staat und Strafe. Diss. jur., Frankfurt am Main, 1922.

PALLAMOLLA, Raffaella. A Construção da Justiça Restaurativa no Brasil e o Protagonismo do Poder Judiciário: permanências e inovações no campo da administração de conflitos. Tese de Doutorado, Programa de Pós-Graduação em Ciências Sociais da PUCRS, Porto Alegre, 2017.

PALLAMOLLA, Raffaella. Justiça Restaurativa: da teoria à prática. São Paulo: IBCCRIM, 2009.

PASTORAL CARCERÁRIA. Tortura em Tempos de Encarceramento em Massa. São Paulo: ASAAC, 2016.

PAVARINI, Massimo. Castigar al Enemigo. Quito: Flacso, 2009, pp. 59-80.

PAVARINI, Massimo. Control y Dominación: teorias criminológicas burguesas y proyecto hegemónico. 2. ed. Madrid: Siglo XXI, 1988.

PIRES, Thula. Criminalização do Racismo: entre a política de reconhecimento e meio de legitimação do controle social sobre os negros. Brasília: Brado Negro, 2016.

PRADO, Geraldo; CASARA, Rubens. Dispositivos Legais Desencarceradores: o óbice hermenêutico. In: ABRAMOVAY, Pedro V.; BATISTA, Vera Malaguti (orgs.). Depois do Grande Encarceramento. Rio de Janeiro: Revan, 2010.

PRADO, Geraldo. Sistema Acusatório: a conformidade constitucional das leis processuais penais. Rio de Janeiro: Lumen Juris, 1999.

PRADO, Geraldo. Transação Penal. 2. ed. Rio de Janeiro: Lumen Juris, 2006. REIS, Vilma. Juristas Negros e Negras por Vida e Liberdade no Brasil. In: Discursos Negros: legislação penal, política criminal e racismo. Brasília: Brado Negro, 2015.

ROODAS, Sérgio. Palavra de policiais é o que mais influencia juízes em casos de tráfico, diz pesquisa, Conjur, 23/02/2018 [disponível em https://www.conjur.com.br/2018-fev-23/palavra-pm-influencia-casos-trafico-estudo] 
RUGGIERO, Vincenzo. An Abolitionist View of Restorative Justice. International Journal of Law, Crime and Justice, v. 39, n. 2, 2011.

SINHORETO, Jaqueline. Seletividade Penal e Acesso à Justiça. In: LIMA, Renato S. et al (orgs). Crime, Polícia e Justiça no Brasil. São Paulo: Contexto, 2014.

STABILE, Arthur. Tortura tem impunidade plena no sistema prisional, aponta relatório da Pastoral Carcerária, Ponte Jornalismo, 20/10/2016 [disponível em https://ponte.org/tortura-tem-impunidade-plena-no-sistema-prisional-aponta-pastoral-carceraria/]

STF-Supremo Tribunal Federal. Ação Direta de Inconstitucionalidade 6.298 (Decisão Cautelar Min. Dias Toffoli), STF, Rel. Min. Luiz Fux, 15/01/2020 [disponível em http://www.stf.jus.br/arquivo/cms/noticiaNoticiaStf/anexo/ Juizdasgarantias.pdf]

SWAANINGEN, René van. Perspectivas Europeas para una Criminología Crítica. Buenos Aires: BdeF, 2011.

SWAANINGEN, René van. Reclaiming Critical Criminology: social Justice and the european tradition. Theoretical Criminology, v. 3, n. 5, 1999. VAN NESS, Daniel W.; STRONG, Karen Heetderks. Restoring Justice: an introduction to restorative justice, 4. ed., New Providence, Anderson Publishing, 2010.

ZAFFARONI, Eugenio Raúl. La Palabra de los Muertos: conferencias de criminologia cautelar. Buenos Aires; Ediar, 2011.

ZEHR, Howard. Changing Lenses: a new focus for crime and justice. Scottdale/EUA: Herald Press, 1990.

ZACCONE, Orlando. Indignos de Vida. Rio de Janeiro: Revan, 2015.

\section{SALO CARVALHO}

Professor adjunto de direito penal e criminologia da Faculdade Nacional de Direito (UFRJ) e do programa de pós-graduação (mestrado e doutorado) em direito da Unilasalle/RS; mestre (UFSC) e doutor (UFPR) em direito, com estudos de pós-doutorado na 
Universidade Pompeu Fabra (Barcelona), Universidade de Bolonha e PUCRS.

Endereço profissional: Faculdade Nacional de Direito, UFRJ, R. Moncorvo Filho, 8 - Centro, Rio de Janeiro - RJ, 20211-340, Brasil.

ORCID ID: https://orcid.org/0000-0002-2006-9916

E-MAIL: salo.carvalho@uol.com.br

\section{DANIEL ACHUTTI}

Professor de direito processual penal no IBGEN/RS e de justiça restaurativa na Escola Justiça Restaurativa Crítica; mestre e doutor em ciências criminais (PUCRS), com estudos de pós-doutorado na Universidade de Leuven, Bélgica. Advogado.

Endereço Profissional: IBGEN, Av. Praia de Belas, 1510 - Praia de Belas, Porto Alegre - RS, 90150-071, Brasil.

ORCID ID: https://orcid.org/0000-0002-2843-3305

E-MAIL: daniel.achutti@achuttieosorio.com.br

Recebido: 12/07/2020

Aceito: 03/11/2020 